\title{
THE PLASMA PROTEINS IN RELATION TO BLOOD HYDRATION. VI. SERUM PROTEINS IN NEPHRITIC EDEMA
}

By JOHN P. PETERS, FREDERICK S. BRUCKMAN, ANNA J. EISENMAN, PAULINE N. HALD AND A. MAURICE WAKEMAN

(From the Department of Internal Medicine of Yale University and the Medical Service of the New Haven Hospital, New Haven)

(Received for publication July 13, 1931)

The total proteins of the serum have been determined 179 times in 21 patients with nephrosis or nephrotic types of nephritis. On 118 occasions in 15 patients albumin and globulin fractions were determined separately.

The methods employed for analysis of the serum have been described elsewhere (1).

\section{Nature of clinical material}

Abstracts with the most significant clinical features of each case may be found at the end of the paper. From consideration of these protocols it becomes at once evident that the clinical material is so far from homogenous that the propriety of discussing it under a single head may be questioned. The cases can be divided roughly into three groups. From the standpoint of both etiology and course the first eight patients clearly deserve a diagnosis of glomerular nephritis. With the possible exception of the third case, 61090, the disease was in every instance preceded by sore throat, and was usually ushered in by an acute stage in which hematuria and transitory hypertension and azotemia were noted. In number 61090 the onset was insidious, but the initial hypertension and azotemia and the subsequent course of the disease were quite typical of glomerular nephritis.

Of the next five patients, three $(34753,56577$ and 72481$)$ were proved at autopsy to have amyloid nephrosis, the other two probably had the same condition. It is not at all unlikely that the succeeding two, 50625 and 15544 , also had amyloid disease; both had active pulmonary tuberculosis. 
The last five have been grouped together merely because the etiology is in every case uncertain. Four of them, 73222, 29122, 80351 and 62246, conformed more exactly than any of the other patients in the series to
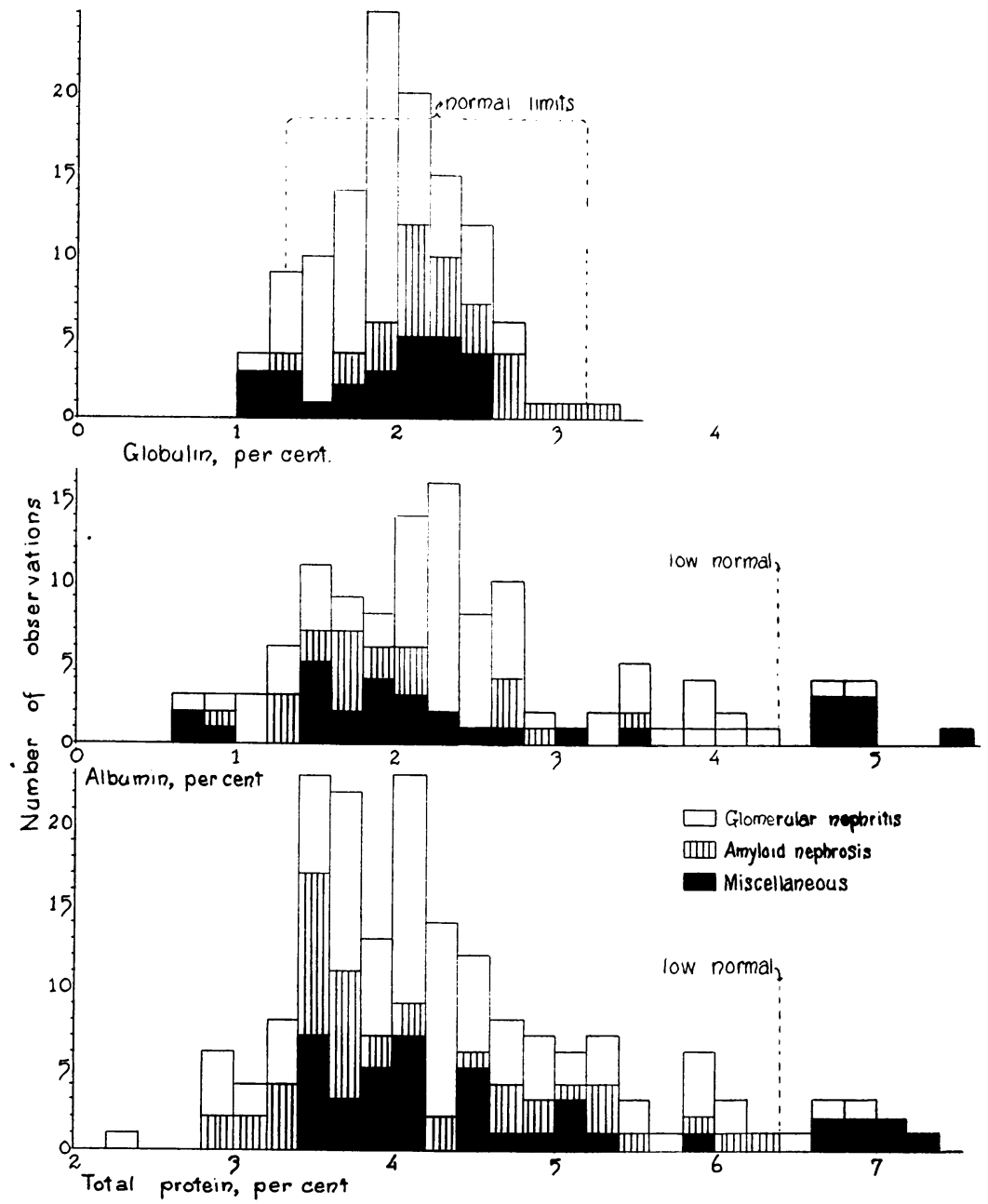

Fig. 1. The Relation of Serum Proteins to the Type of Nephritis

Epstein's (2) description of nephrosis. The origin of the disease was insidious, without antecedent infection and unaccompanied by hypertension; azotemia was observed only in 73222 for a short time after admission; hematuria was absent or minimal. 
On the other hand, all the patients, at one time or another, usually over considerable periods, exhibited clinical and functional pictures indistinguishable from that described by Epstein (2) as characteristic of nephrosis; edema, massive albuminuria and reduction of serum proteins, without nitrogen retention, high blood pressure, or gross or microscopic hematuria. Basal metabolism and serum cholesterol, which were determined in a certain proportion of the cases, served no better to differentiate "pure nephrosis" from the other renal conditions. In another paper (3) it has been demonstrated that the electrolyte abnormalities in the different groups of cases are no more distinctive.

All these facts seem to justify discussion of the functional disturbances in this group as a unit and raise the question whether "nephrosis," as a clinical term, is more than a convenient means of describing a syndrome that may occur in the course of renal diseases originating from a variety of causes.

How impossible it is to differentiate nephrosis from glomerular nephritis and amyloid disease of the kidneys by means of the serum proteins can be seen from Figure 1. Both total protein and albumin may be quite as low in one disease as another. Globulin tends to be somewhat higher in amyloid nephrosis than in the other conditions. This is presumably referable to the chronic infectious process and not to the renal lesion $(1,4)$. The globulin increases are not great enough or consistent enough to aid in the diagnosis of amyloid disease.

\section{Relation of edema to total serum protein}

The relation of serum proteins to edema in this series is illustrated, by means of frequency charts, in Figure 2. The close correlation is at once apparent. Edema was almost invariably present when total proteins were below 4 per cent, while it was observed in only three instances when the proteins were above 5 per cent. The latter exceptions to the general rule, moreover, occurred in two patients, 15544 and 83434 , who had in addition to renal disease, distinct signs of heart disease with circulatory failure.

Although it was sometimes possible to induce some degree of diuresis while the proteins were below 4 per cent, complete elimination of edema was effected under these circumstances in only one instance. In this instance serum albumin was relatively high, 2.39 per cent, while globulin was quite low, 1.34 per cent. 


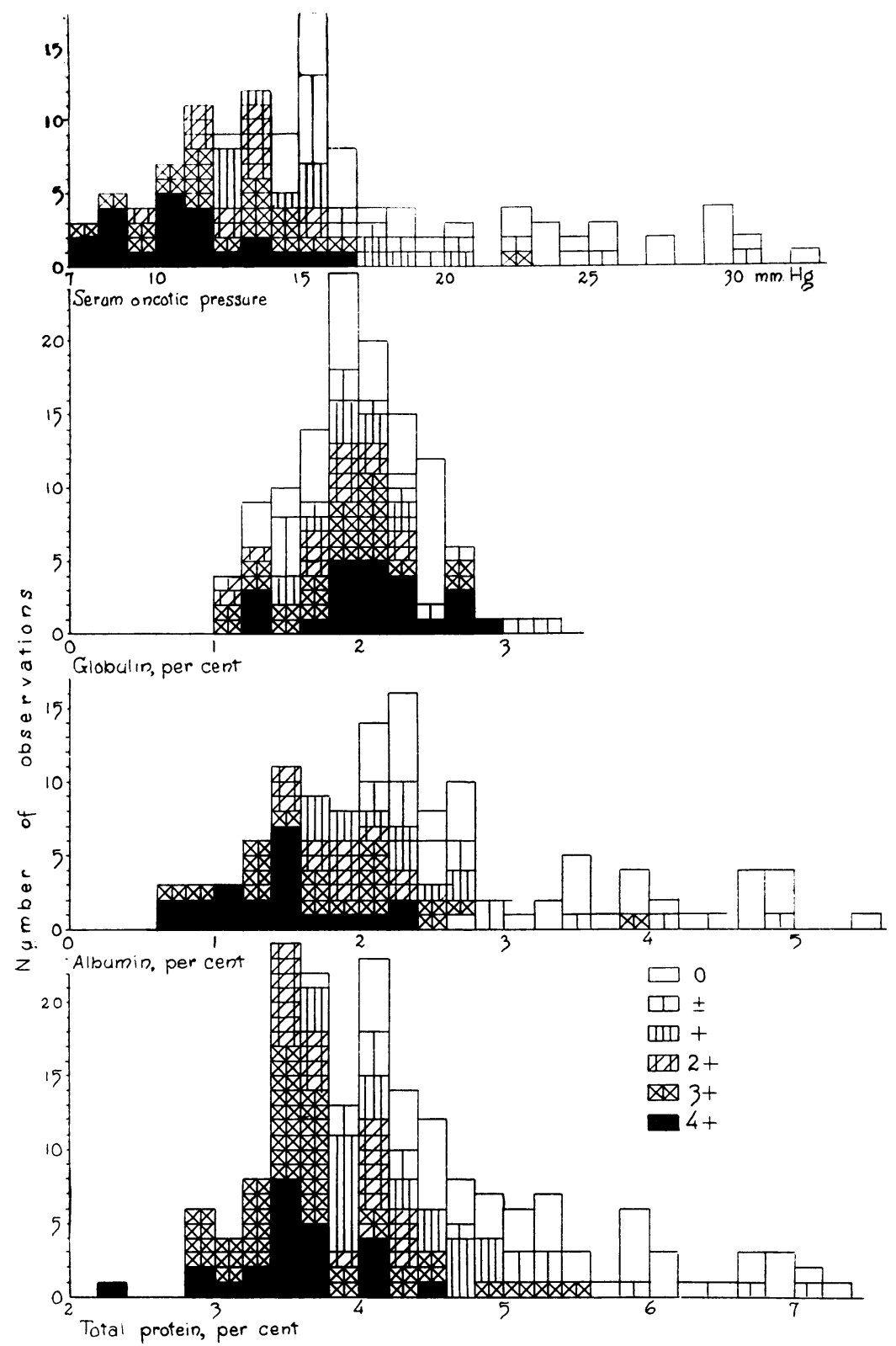

Fig. 2. The Relation of Edema to the Serum Proteins

Estimation of the degree of edema is quite rough. \pm indicates slight puffiness of the feet noticed by ambulatory patients at the end of the day: + represents persistent, demonstrable swelling of the feet; $2+$ more extensive subcutaneous edema; $3+$ subcutaneous edema and serous effusions: $4+$ extreme general anasarca.

Oncotic pressure was calculated from the serum protein values by the factors of Govaerts: $(5.5 \times$ per cent ablumin $)+(1.4 \times$ per cent globulin $)$ $=$ oncotic pressure in $\mathrm{mm}$. $\mathrm{Hg}$. 
With proteins between 4 and 5 per cent edema was sometimes present, sometimes absent. Altogether, demonstrable edema was observed 36 times when the proteins were within this range. Of these 36 observations 20 were made either before treatment was instituted or during periods of diuresis. In these cases either treatment was effectual in eliminating edema or else the serum proteins fell below 4 per cent. Edema persisted in case 83166 , in spite of the fact that the proteins rose above 4 per cent, during an intercurrent attack of acute nephritis. In acute nephritis edema does not seem to depend directly on the serum protein level $(5,6,7)$. In another instance, case 73222 , there was a transitory rise of protein to 4.04 without diuresis during the terminal period of septicemia when the patient had been vomiting continuously. One of the observations was made on case 15544, the patient with heart failure noted above; 8 on case 34854 , who proved to have rheumatic heart disease. The 3 remaining instances represent merely transitory rises to between 4.0 and 4.1 per cent.

In this series, therefore, it proved possible in every instance to eliminate edema by treatment when the proteins persistently exceeded 4 per cent, unless there was concomitant cardiac disease with decompensation or a complicating acute nephritis or septicemia. The treatment employed consisted of restriction of salt to 2 grams or less of $\mathrm{NaCl}$ daily, with little or no restriction of fluids. In addition ammonium chloride or urea or both were given when salt restriction alone proved ineffectual. Under more strenuous treatment it might have been possible to eliminate edema at lower serum protein levels.

In similar studies Moore and Van Slyke (5) found edema in no case when the serum protein exceeded 5.5 per cent. Fahr, Kerkhoff and Conklin (8), found proteins below 4.8 per cent in patients with nephritic edema.

\section{The relation of edema to serum protein fractions and oncotic pressure}

When the proteins were fractionated (see Figure 2), the results obtained were in accord with those of previous observers in showing that the deficiency involves chiefly, if not entirely, the albumin fraction. Globulin lay within normal limits or was slightly elevated. The relation of this hyperglobulinemia to the underlying infectious processes has already been mentioned. From molecular weight determinations 
$(9,10)$ it has been established that the albumin molecule is smaller than that of globulin. A given concentration, by weight, of albumin, therefore, must exert a greater osmotic pressure than the same concentration of globulin. Govaerts (11) has estimated that the osmotic pressure of a 1 gram per cent solution of albumin in serum is $5.5 \mathrm{~mm}$. $\mathrm{Hg}$, while that of a similar solution of globulin is only $1.4 \mathrm{~mm}$. According to the theory of Starling (12) a specific deficit of albumin should be more effective in producing edema than an equivalent reduction of albumin. It might be hoped that the albumin deficit or, better still, the oncotic (colloid osmotic) pressure, estimated by the factors of Govaerts, would be related to the occurrence of edema more closely than the total serum proteins.

In the present series of cases the correlation of edema with either albumin concentration or oncotic pressure (Figure 2) is not appreciably better than that with total protein, merely because there is such a close correlation between the concentrations of total protein and albumin. Cases may be found in which globulin is increased to such an extent that edema may occur at protein concentrations above 5 per cent. Cases of this kind have been described in a previous paper on malnutritional edema (1). An especially striking example was recently observed in a patient with cirrhosis of the liver and emaciation with intractable generalized subcutaneous edema. The edema was believed to be due to malnutrition and low serum proteins were expected. The proteins, which were determined on several occasions, varied from $\mathbf{5 . 9 0}$ to 7.23 per cent, within or just below the normal limits. However, albumin was greatly reduced, 1.52 to 1.97 per cent, globulin making up the greater part of the proteins, 4.27 to 5.26 per cent. The oncotic pressure of the serum, estimated by Govaerts' factors (11), varied from 14.5 to $18.2 \mathrm{~mm}$. $\mathrm{Hg}$ quite as low as the values found in patients with nephritic edema.

Salvesen (13) has reported a case of nephrosis with syphilis in which serum globulin was sufficiently increased to compensate osmotically for a considerable albumin deficiency and to prevent edema. The authors have encountered a similar case with general myelomatosis. The total serum proteins varied from 9.8 to 13.1 per cent, the albumin from 2.2 to 2.9 per cent, the globulin from 7.1 to 10.6 per cent. The oncotic pressure of the serum calculated by Govaerts' factors varied 
from 24.9 to $30.3 \mathrm{~mm}$. Hg. Although the albumin was reduced to the point at which edema is prone to occur in nephritis, the estimated oncotic pressure lay at all times above the level at which edema has been found to appear.

In the present study edema was present on every occasion when the serum albumin was below 2 per cent, but in only one instance when it exceeded 2.75 per cent. This exception is the case (83434) with heart block noted above. The observations with edema in the intermediate zone, 2.0 to 2.75 per cent, are composed chiefly of untreated or responsive cases. The dividing zone, in terms of oncotic pressure, seems to lie between 14 and $21 \mathrm{~mm}$. $\mathrm{Hg}$, with the same exception, case 83434 , presenting edema, probably partly of cardiac origin, at an oncotic pressure of $22.9 \mathrm{~mm}$.

These results are in keeping with those of other observers. Moore and Van Slyke (5) found edema only when serum albumin fell below 2.5 per cent. Fahr, Kerkhoff and Conklin (8) found that the serum oncotic pressure, determined by the method of Schade, was less than $17 \mathrm{~mm} . \mathrm{Hg}$ in patients with nephritic edema. Cope (6), using the osmometer of Verney, found oncotic pressures varying from 8 to $38 \mathrm{~mm}$. $\mathrm{Hg}$ in a group of edematous nephritics. The higher values were observed in the earlier stages of acute nephritis.

In the literature much weight has been attached to the albumin: globulin ratio. As it has been established that the concentrations of these two protein fractions in the serum are determined by entirely different factors and that the two fractions are probably functionally unrelated (1), the value of employing such a ratio is doubtful. It is not the proportion of albumin to globulin, but the absolute concentration of albumin, that is important in the edematous nephritides. A low albumin : globulin ratio due to reduction of albumin has a significance entirely different from that of an equally low ratio due to elevation of globulin.

\section{The causes of the serum albumin deficiency}

That the serum protein deficiency is not due simply to altered blood volume could be inferred from the fact that the two protein fractions are not equally affected. More direct evidence is found in studies of the serum volume. Linder, Lundsgaard, Van Slyke and Stillman (14) 
made repeated determinations of the serum proteins and the serum volume (by the dye method) in a group of patients with chronic nephrosis or nephrotic glomerular nephritis. In no case was the serum volume appreciably above normal. Fluctuations of serum proteins and variations of edema were not attended by comparable changes of serum volume. Brown and Rowntree (15) detected no abnormalities of serum volume in patients with renal edema. Darrow (16) noted a tendency to blood concentration during the edematous stages of nephritis in children. If the theory of Starling (12) offers a satisfactory explanation for the pathogenesis of edema, the blood should not share in the edema, which is due to the inability of the organism to retain fluid in the vascular bed.

It is generally believed, on the basis of indirect evidence of various kinds, that urinary albumin is derived directly from serum albumin which escapes from the blood circulating through the kidney, probably because of abnormal glomerular permeability. If this is the case albuminuria must be considered a serious cause of serum albumin wastage. A patient of average size losing as much as 16 grams of protein a day, as did some of the cases in this series, would excrete all the albumin of his serum in the course of a week or two. Plasmapheresis experiments on dogs $(17,18)$ indicate that such a rate of removal seriously taxes the regenerative capacity. If the human capacity for protein regeneration is no greater than that of the $d o g$, the urinary protein excretion of some patients in the present series must approach the limit of the regenerative powers of the body.

Nevertheless, as can be seen from Figure 3, the serum albumin deficit is not directly related to the degree of albuminuria. This lack of correlation holds not only for the group of patients, but also for those individuals who were observed over a sufficiently long period to permit valid comparisons to be made. Some of the patients with maximum albuminuria had relatively high serum proteins. Urine protein was determined by analyzing the urine for nitrogen before and after precipitation with trichloroacetic acid. In cases 35628, 61090, 34854, 95123, $83166,50265,80351$ and 62246 serum albumin rose during the period of observation in spite of the fact that the degree of proteinuria remained practically unaltered. Therefore, although proteinuria is undoubtedly responsible, it is not solely responsible for the production of the serum protein deficit of the edematous nephritic. 
It has been demonstrated by Frisch, Mendel and Peters (19) that serum protein deficit and edema can be produced in rats by the administration of diets containing insufficient amounts of protein. Furthermore, in earlier papers of this series $(1,20)$ it has been shown that serum albumin is regularly low in patients with malnutrition and may be restored to the normal level by the administration of diets with high protein and high calories. Ling (21) and Weech and Ling (22) have reported low serum albumin in Chinese famine victims. That nephri-

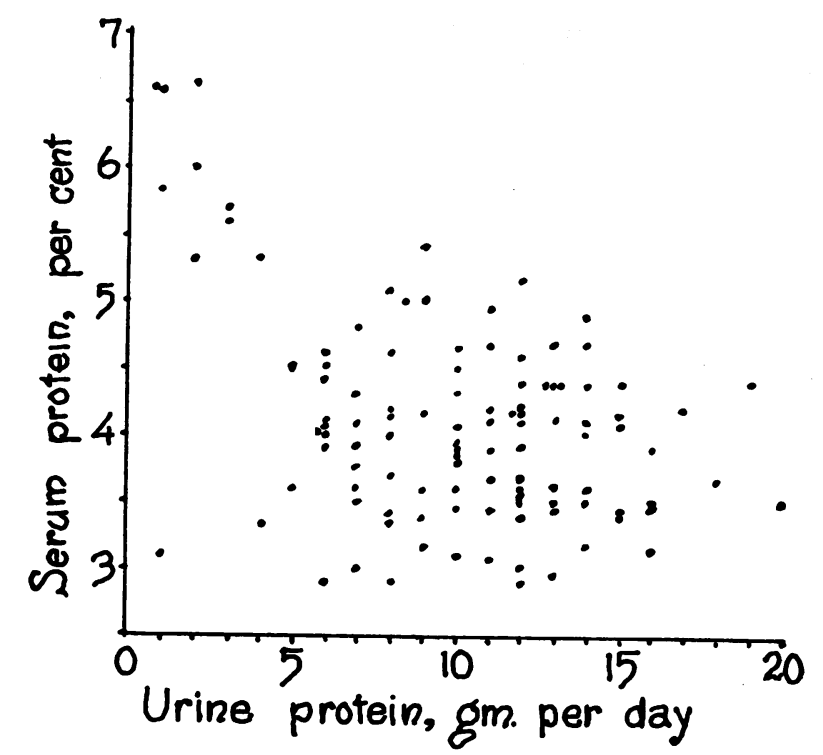

Fig. 3. Relation of Serum Protein to Urine Protein

tis is a wasting disease has been clearly recognized by Bright and subsequent observers and has been emphasized by one of the authors (23). All these observations taken together suggest that malnutrition, or more specifically protein starvation, may be a factor in the production of the serum albumin deficiency in edematous nephritis.

An attempt has been made to estimate the state of nutrition in each case. This is difficult because the usual criteria of weight and appearance are of little value in the presence of edema. On the basis of other types of evidence, which are indicated in the following abstracts, it is possible to state that of the 21 patients 14 were unmistakably malnourished at the times when they presented edema and low serum proteins. 


\section{Evidences of malnutrition}

35628: Weight with edema 76.4 kilos; after diuresis, in spite of long positive nitrogen balance, 63.6 kilos. Patient a farmer about 6 feet tall.

61711: Lowest weight, while still presenting general edema and ascites, 15.0 kilos, below low standard weight for age of 5 . Had extreme anorexia and gastro-intestinal disturbances.

61090: After relief from edema weight was only 45.4 kilos, in comparison with a normal weight of 66 kilos. Edema recurred on a subsequent occasion after restriction of diet.

34854: Weight after diuresis only 62.7 kilos, although he was very tall.

56883: Weight without edema 64.1 kilos, height $183 \mathrm{~cm}$.

95123: When first seen quite stout; but had received diet with limited protein for a long period. Edema recurred at a subsequent time when she restricted protein and calories voluntarily.

83166: Normal weight reported to have been 66.0 kilos. At height of edema weighed only 73.2. While still in state of general anasarca weighed only 67.5.

$F$. $M .:$ No edema, nutrition fair.

34753: Tuberculous enteritis, evidently wasted.

56577: Pelvic osteomyelitis. Extreme wasting. Edema recurred after recurrence of osteomyelitis, associated with anorexia and vomiting.

72481: Advanced pulmonary tuberculosis with enteritis and emaciation. Weight with edema only 51.8 kilos.

72804: Advanced pulmonary tuberculosis with extreme wasting.

58114: Advanced pulmonary tuberculosis in emaciated terminal condition.

50265: Weight after diuresis 51.6 kilos. Weight after recovery, without edema, 65.8 .

15544: Never weighed in state of normal nutrition without edema. A tuberculous diabetic who had been wasting steadily until the edema appeared.

31190: Weight with little edema 73.3 kilos; height $166 \mathrm{~cm}$. Seemed well nourished.

73222: Boy 6 feet tall weighed only 76.2 kilos when completely waterlogged. Symptoms had been extreme anorexia, nausea and vomiting.

83434: Extremely wasted and anemic after prolonged anorexia and vomiting.

29122: Weight with edema 69.1 kilos; after diuresis 59.7 kilos. Height $159.5 \mathrm{~cm}$. Therefore apparently well nourished. History quite imperfect.

80351: Weight with edema 76.8 kilos; normal weight about 69.0. Edema preceded by anorexia, nausea and vomiting.

62246: Seemed rather obese; but among the chief symptoms were anorexia, nausea and vomiting. 
Some of the subjects at the height of their edema, weighed considerably less than the sum of the normal body weight plus the weight of edema. For example, 73222, who was 6 feet tall and normally weighed 79.5 kilos, weighed only 81.8 kilos when he was admitted to the hospital with massive, generalized, subcutaneous edema, ascites and double pneumothorax.

Others when they had rid themselves of their edema were found to be far below normal weight, emaciated shadows of their former selves. The best example of this is found in 61090 , whose data are presented in detail in Table 1. When she was admitted to the hospital with general anasarca she weighed 96 kilos. When all her edema had been eliminated she weighed only 45.4 kilos in spite of the fact that she had put on tissue, as evidenced by a large positive nitrogen balance. Her usual weight before the onset of the nephritis had been 67.3 kilos. The subsequent history of the case is significant. On a high protein diet she resumed her normal weight and her serum proteins gradually rose from an initial low point of 3.20 per cent, July 6, 1927, to 6.96 per cent, January 29, 1930, in spite of persistent proteinuria. In the latter part of 1930 , two and one half years after the onset of the disease she reduced her diet somewhat in the interest of her figure. The proteins, on November 13 were found to have fallen to 5.95 per cent. Early in 1931, during an acute respiratory infection she developed an exacerbation of the nephritis accompanied by anorexia, nausea and vomiting. The proteins fell sharply, reaching a low point of 3.39 on January 22. With return of appetite and resumption of a high protein diet they rose again quite rapidly, although the albuminuria persisted.

Further evidence of protein starvation is found in nitrogen metabolism studies, which were made on cases 35628, 61711, 61090, 34854, 51883, 95123, 83166, 34753, 56577, 50625, 73222, 80351 and 62246. In all these cases when diets containing high calories and more than maintenance quantities of protein were taken, large positive nitrogen balances were established and maintained for periods varying from 17 to 117 days. The data from two of these patients, 34854 and 35628 , have been presented elsewhere ((24), cases 1 and 2). Those obtained from other patients are essentially similar. In the earlier studies urine alone was analyzed for nitrogen. To demonstrate conclusively that the positive balances were real and significant stools from 61090, 95123, 


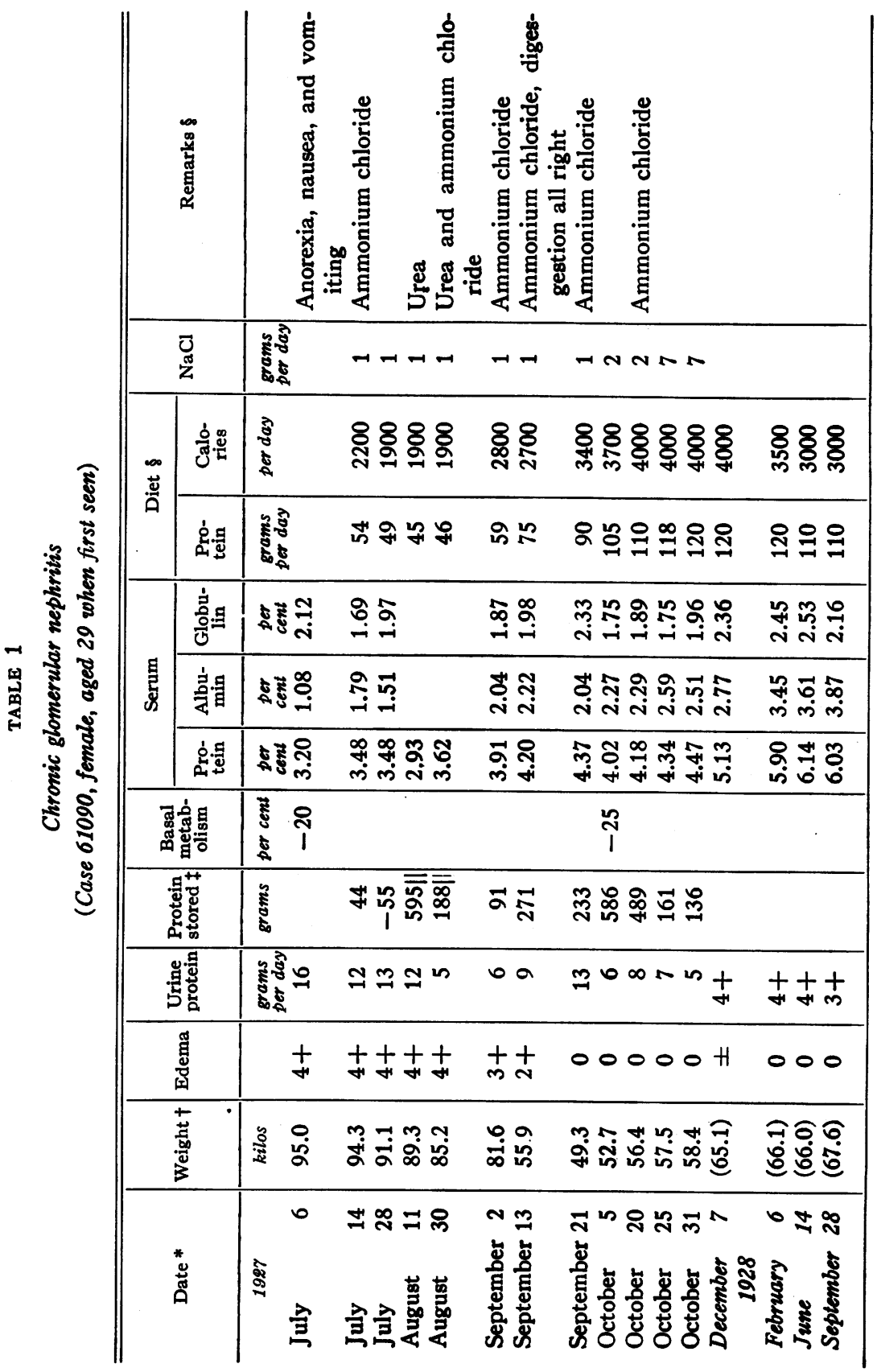




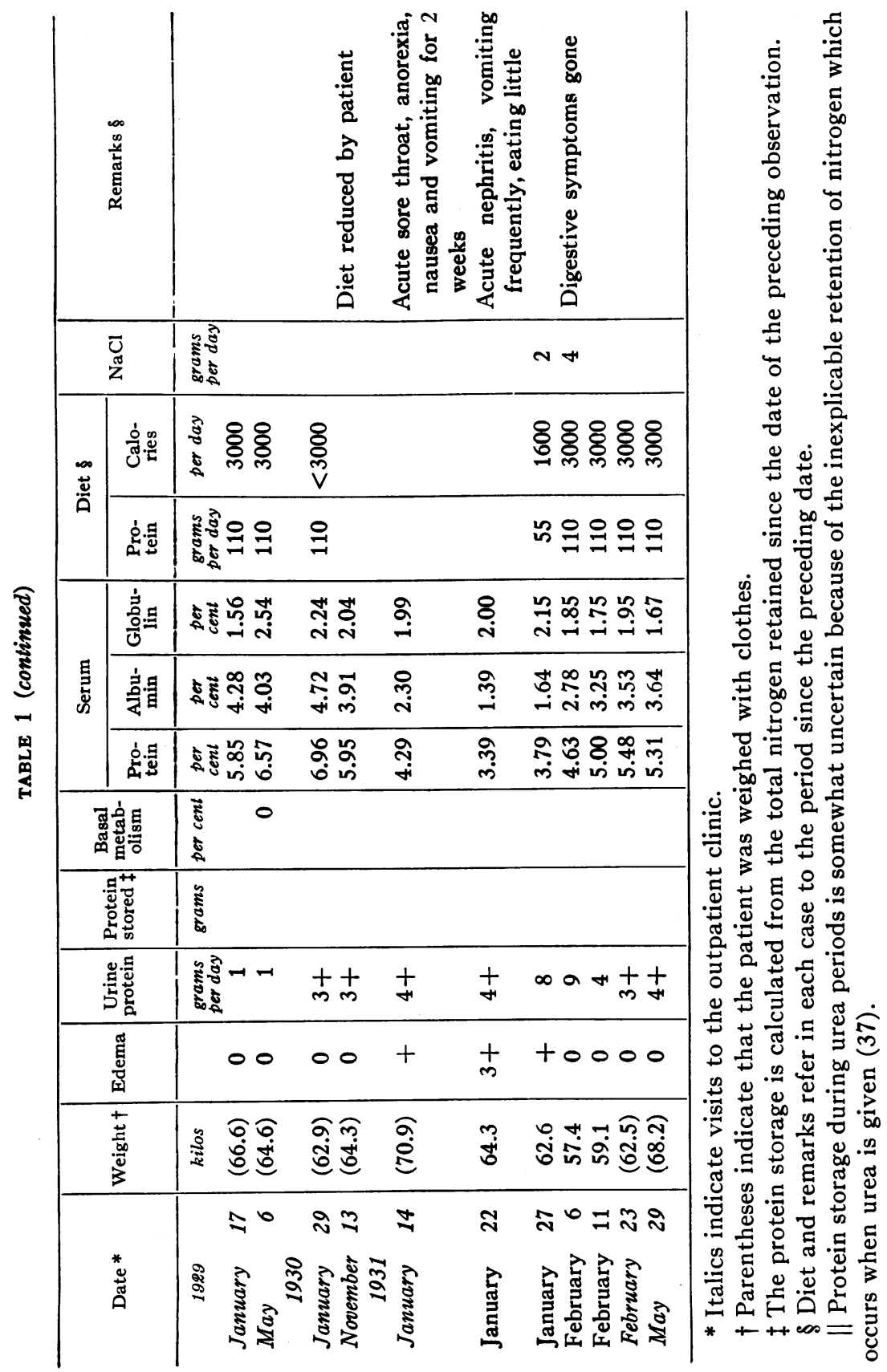


$83166,34753,73222$, and 62246 were also analyzed. It is generally assumed that prolonged positive nitrogen balances can be obtained on adults only after a period of protein starvation. The positive balances in the cases here reported may, therefore, be considered as direct proof of protein deficiency or malnutrition. Similar individual cases with prolonged positive nitrogen balances have been reported by Mason (25), Rabinowitch and Childs (26), and Cowie, Jarvis and Cooperstock (27).

Of especial importance are the 7 patients who did not appear to be unmistakably malnourished: 51883, F. M., 95123, 31190, 29122, 80351 and 62246. In two of these, 31190 and 29122, seen before the importance of the nutritive state was recognized, the data are too incomplete to permit adequate analysis. F. M., a patient with a chronic glomerular nephritis with moderate albuminuria, had normal serum proteins and no edema. Number 51883, with a similar condition, was free from edema and had a slight serum protein deficiency, 5.31 per cent. He had subsisted for some time, under the directions of his physician, on a low protein diet. With only 75 grams of protein and 3000 calories he stored, in 15 days, nitrogen equivalent to 151 grams of protein. During this period the serum proteins rose to 5.68 per cent. Number 80351 had recurrent transient attacks of nephrosis, each one of which terminated rapidly after admission to the hospital, with apparently complete restoration of renal integrity. Each one of these attacks was initiated by a period of anorexia, nausea and vomiting, necessitating restriction of diet. During the one period in the hospital in which nitrogen metabolism was determined, a considerable amount was stored. At the same time the serum proteins rose from 3.87 to 4.81 per cent while the urine protein excretion remained constantly between 5 and 7 grams per day. In an earlier period, with a urine protein excretion of only 2 grams per day, under the influence of similar digestive disturbances, the serum proteins fell from 6.79 to 5.97 per cent, while the weight diminished from 69.5 to 66.8 kilos. Edema did not appear. The important data in the case are presented in Table 2.

Number 62246, when she first entered the hospital, appeared distinctly obese, and her subsequent course clearly indicated that this appearance was due to substantial fat deposits in addition to edema. Nevertheless, the serum proteins were reduced. Again, as in the last 
PETERS, BRUCKMAN, EISENMAN, HALD AND WAKEMAN

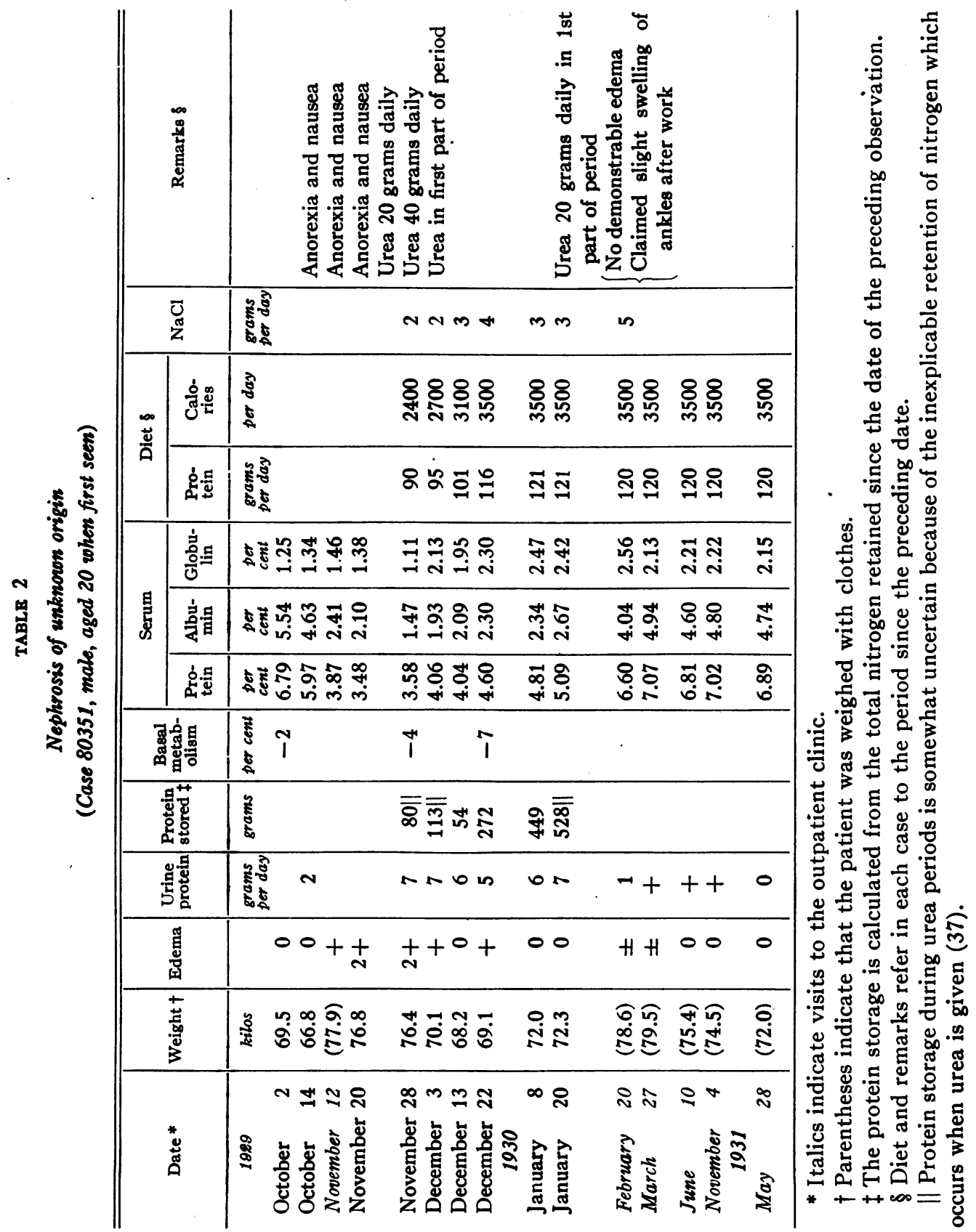


case, the chief symptoms were referable to the digestive tract, anorexia, nausea and vomiting. These symptoms effectually thwarted attempts to give a high protein diet. Over a period of 5 months the average protein intake per day in no period exceeded 70 grams and for the first 2 months was only 50 grams. Meanwhile the edema stubbornly resisted treatment and the serum proteins as persistently remained below. 4 per cent. Six months after her first admission the digestive disturbances began to diminish and her diet gradually increased. Unfortunately the next blood examination was not made until 10 months later. By this time the proteins had risen to 4.53 per cent and she had only occasional orthostatic edema. The proteins in another 3 months had risen to 5.25 per cent with disappearance of the last vestiges of edema, although the proteinuria remained apparently unaltered. Further investigation of the effects of diet were frustrated by complete disappearance of the nephrotic syndrome with apparent restoration of normal kidney function. The important data in this case are presented in Table 3.

Case 95123 (see Table 4) was first seen in June 1928, when edema had persisted for a period of 6 years, under treatment consisting chiefly of protein restriction. At this time her excessive weight of 86.2 kilos was only partly referable to edema, chiefly to adiposity. The serum proteins were 4.07 per cent. Under treatment with a diet of 80 grams protein, 2000 calories, moderate salt restriction and urea, the edema disappeared and the proteins gradually rose to reach 5.89 per cent in November. About this time in behalf of her figure, at the request of the patient, the calories were reduced to 1500 . The serum proteins had again dropped below 5 per cent by May, 1929, and after this failed to rise again even when protein and calories were apparently greatly increased. Subsequent questioning revealed the fact that the patient had not followed her diet prescriptions faithfully, fearing return of her obesity. The extent of her dietary lapses could not be ascertained. Shortly after the examination of May 22, 1930, which marked a new low point of 4.41 per cent for the serum proteins, she reduced her diet more drastically and, when edema shortly appeared, attempted vainly to check her rising weight by further restrictions. Although, when she returned for observation in November, she had subcutaneous edema and ascites, her weight was not appreciably greater than it had been at 
PETERS, BRUCKMAN, EISENMAN, HALD AND WAKEMAN

\begin{tabular}{|c|c|c|c|c|c|c|}
\hline \multirow{13}{*}{ 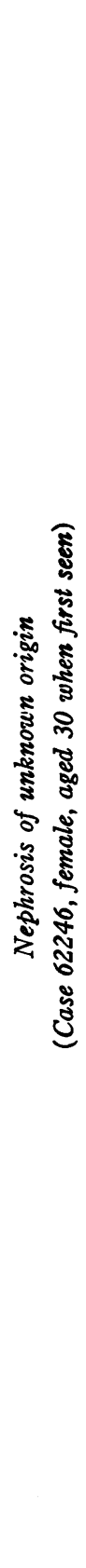 } & 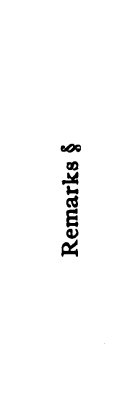 & 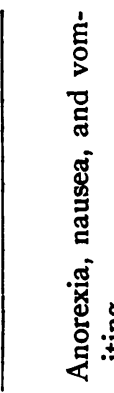 & 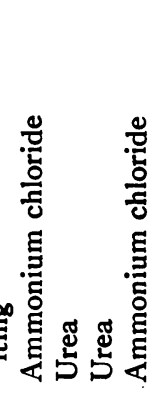 & 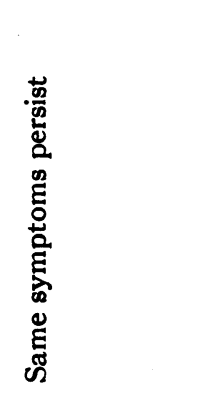 & 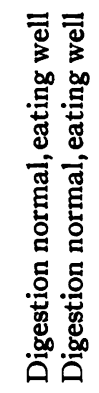 & 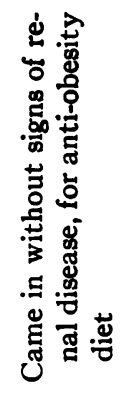 \\
\hline & $\begin{array}{l}\overline{\tilde{c}} \\
\text { z }\end{array}$ & 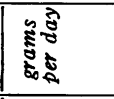 & NNNN & $N N N N$ & & \\
\hline & 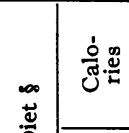 & 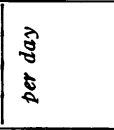 & ి. & 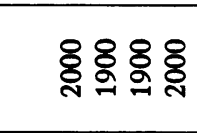 & \&્م & \\
\hline & क्ष: & 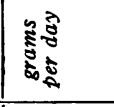 & 怙和品品 & ニㅗㅇㅛ & 88 & \\
\hline & 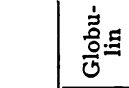 & 홈 & 怘点芯 & $\underset{\text { i }}{\stackrel{i}{i}}$ & $\stackrel{m}{\exists} \vec{i}$ & $\stackrel{\text { I }}{\text { i }}$ \\
\hline & 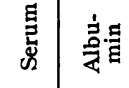 & 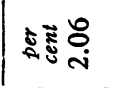 & 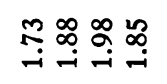 & 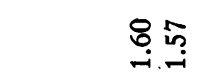 & 勇 & $\underset{+}{\stackrel{+}{+}}$ \\
\hline & 这起 & 호욜 & फ़ં & 임 & 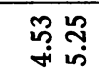 & דָ \\
\hline & 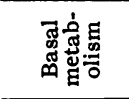 & $\begin{array}{l}\text { हूँ } \\
\text { है }\end{array}$ & iे & & in & \\
\hline & 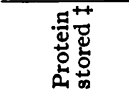 & 喜 & 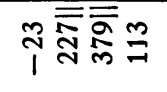 & 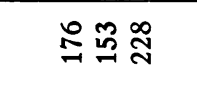 & & \\
\hline & 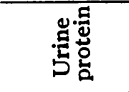 & 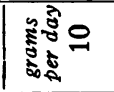 & 오윽 & $\Rightarrow=ㅇ ㅇ ㅇ ㅇ$ & \pm+ & 0 \\
\hline & 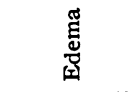 & + & $\begin{array}{l}+++ \\
+++\end{array}$ & $\underset{+}{+}+++\underset{N}{+}$ & $H^{\circ}$ & 0 \\
\hline & 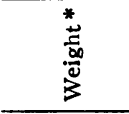 & $\underset{\substack{3 \\
\hdashline}}{\stackrel{n}{\infty}}$ & 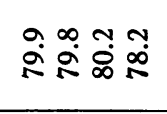 & 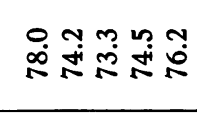 & 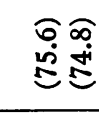 & ลุ. \\
\hline & 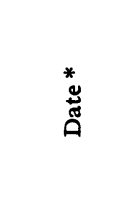 & 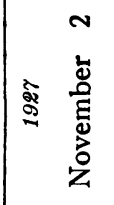 & 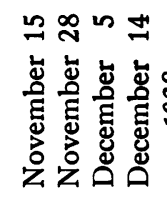 & 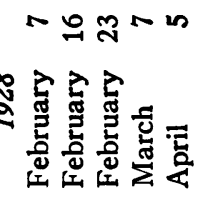 & 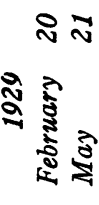 & 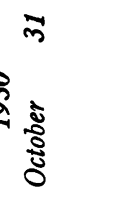 \\
\hline
\end{tabular}

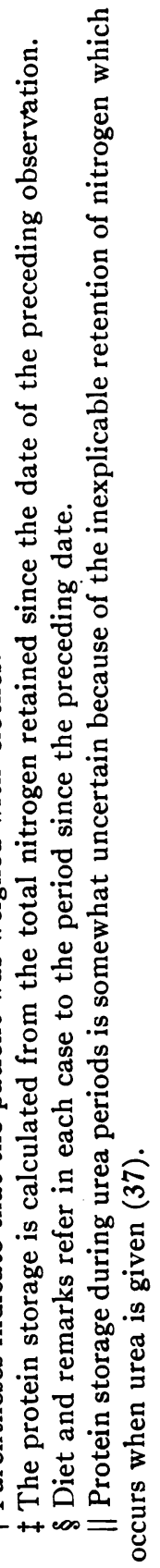


SERUM PROTEINS IN NEPHRITIC EDEMA

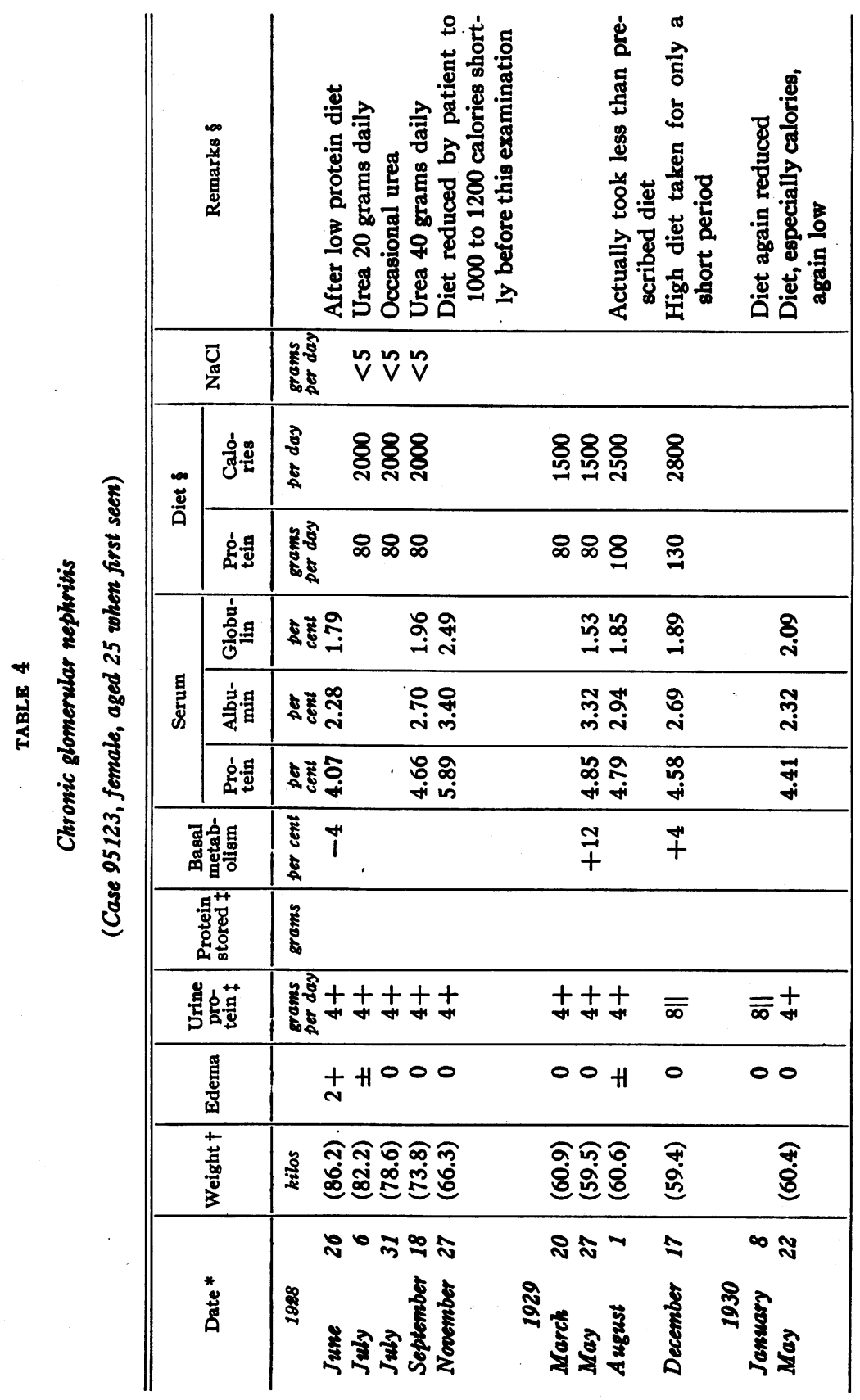




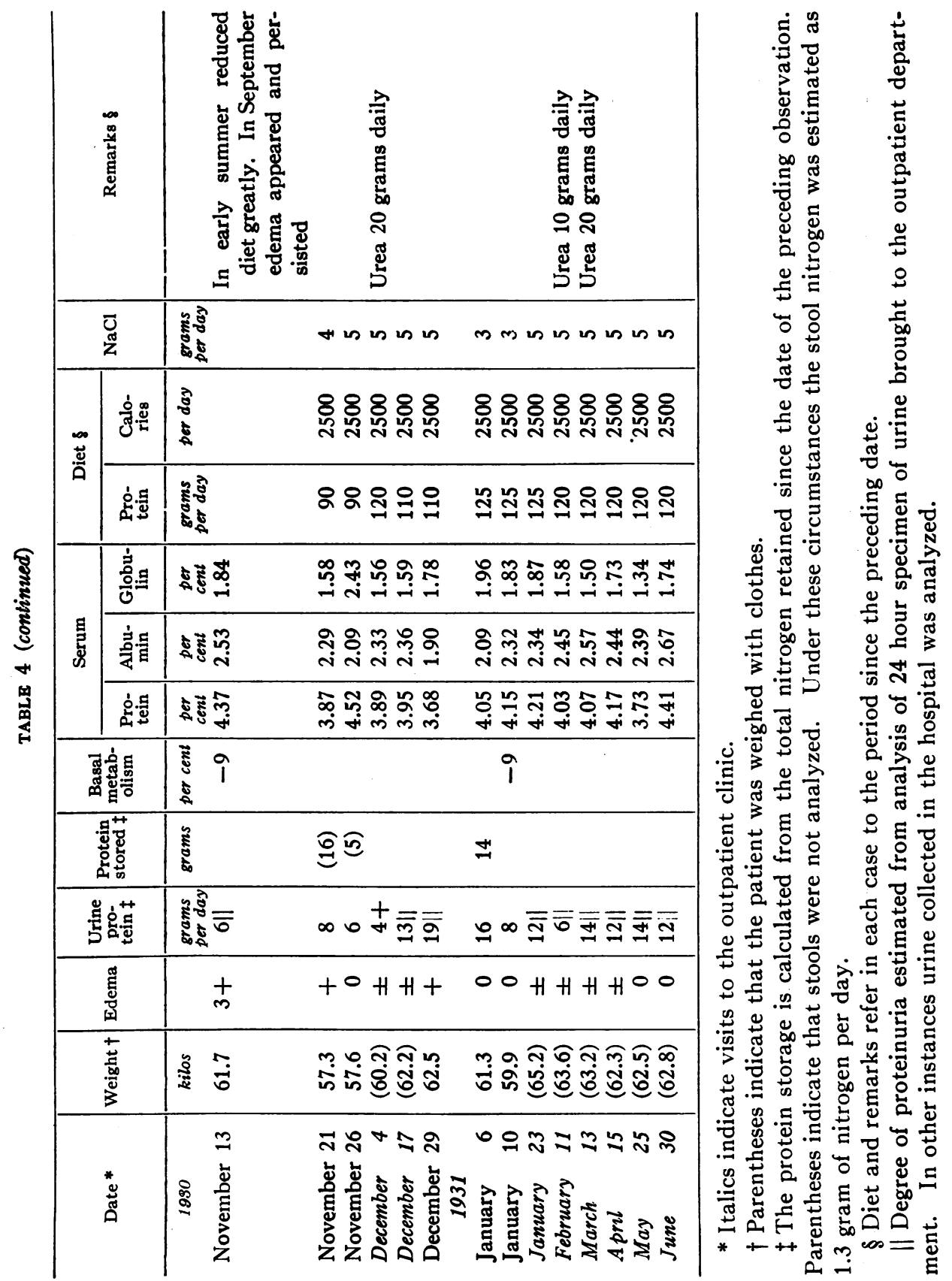


the time of the previous observation. The serum proteins had fallen. With salt restriction, a high protein diet, 2500 calories, and initial use of urea, the edema gradually disappeared when the protein rose above 4 per cent and the albumin above 2.3 per cent.

The evidence of protein depletion in these last cases, though not unequivocal, is distinctly suggestive. If it is accepted, it is clear that malnutrition in the sense of protein wastage is not incompatible with obesity. In a limited sense this has already been proved by studies of the dietary treatment of obesity. Under such treatment there is invariably an initial negative nitrogen balance which does not parallel the loss of body weight. At first nitrogen loss is great in proportion to weight loss; later it diminishes or ceases while the weight continues to fall (28). The organism exhibits a certain, but not perfect, conservative tendency to utilize the indifferent fuel, fat, to spare the functionally important protein. The serum protein deficits which develop in malnutrition of other diseases and in famine victims clearly indicate that the organism to only a limited extent maintains serum albumin at the expense of tissue proteins. If, then, an obese person is afflicted with a proteinuria which continually drains away serum albumin and is, at the same time, by reason of therapeutic restriction, indigestion or other functional disturbances, deprived of an adequate supply of protein, the serum albumin may rapidly fall through failure of the regenerative processes, while consumption of body fat, which is more directly dependent upon caloric needs, may proceed far more slowly.

In patients with true famine malnutrition von Hoesslin (29) and Weech and Ling (22) were unable, by feeding high calories in the form of carbohydrate and fat, without adequate protein, to eliminate edema, to increase weight or to restore the serum proteins to the normal level. The failure to cause weight increases is the more surprising because the basal metabolism, and presumably the caloric needs of malnourished subjects are subnormal. The body weight curves in Ling's cases, after the elimination of edema, at first paralleled closely the nitrogen retention. Somewhat comparable phenomena were observed in some of the nephritics of the present series.

Although 95123, in the earlier periods of study, after the elimination of edema, lost weight extremely slowly on diets of 1500 or 2000 calories, when her weight had fallen and the serum proteins were low, her weight 
remained almost constant on 3500 calories, although her basal metabolism was below normal, giving an estimated basal caloric requirement of only 1340 calories a day. Case 61090 gained weight only slowly on diets containing 3000 to 4000 calories.

\section{Basal metabolism}

Epstein $(2,30,31)$, called attention to the frequent reduction of the basal metabolism in nephrosis, linking it with the lipemia, especially the hypercholesterolemia, and finding in it an indication for and an explanation of the beneficial effects of thyroid medication, which had been advocated by Eppinger. In Epstein's reported cases low basal metabolism occurs more consistently than it does in the literature in general. Nor have others been so uniformly successful with thyroid in the treatment of edema. In the present study basal metabolism was determined 32 times in 10 cases by means of the Roth-Benedict apparatus. In only 6 instances, twice in 61090 with glomerular nephritis, 3 times in 34753 with amyloid nephrosis, and once in 62246 with idiopathic nephrosis, was the basal metabolism below -15 per cent. In 6 instances it was above 0,4 times in the presence of edema. On the whole it seemed to be lowest during the most edematous periods and to rise as the edema disappeared and the general condition improved. However, in 80351, with idiopathic nephrosis, it was -2 and -7 on two occasions in the absence of edema, -4 in one of the edematous periods.

The reduction of basal metabolism that accompanies malnutrition has long been recognized (32) and is emphasized in Ling's (21) reports on famine edema. He found that edema in itself tended to reduce the metabolism (estimated in terms of body surface area) "because the organism is diluted by a large mass of inert fluid." Malnutrition also had an effect. As nutrition improved the metabolism rose sharply at first with the disappearance of edema, more gradually later as nutrition improved. If nephritic edema is attended by malnutrition there is every reason to expect low basal metabolism, especially in the presence of edema.

\section{Therapeutic implications}

Epstein (33) was the first to attach any significance to the reduction of serum albumin as an indication for therapy. Assuming, logically. 
that the low serum albumin was a direct result of leakage of such albumin into the urine, he advocated the administration of high protein diets to patients with nephrosis. Since then numerous others have reported favorable results from the use of generous protein diets. The data here presented offer further reasons for the use of such diets. How much protein should be given is as yet doubtful. In his original paper Epstein advocated 140 grams daily. It is, however, uncertain whether such large amounts can be utilized to advantage. The aim of dietary treatment is not to increase nitrogen catabolism, but to replace wastage and to provide extra protein for the restoration of previously depleted tissues. In the experience of the authors, except when there is infection or some other complicating condition, the protein catabolism of nephritic patients with edema is not abnormally high. In the cases studied during chronic periods it was possible to establish and maintain positive nitrogen balances, even in the face of severe albuminuria, with protein catabolism (estimated from urinary nonprotein nitrogen excretion) not greater and usually less than two thirds of a gram per kilo. In patients with malnutrition from other causes, it has been found that beyond a certain point, increasing increments of protein are used less and less efficiently for storage $(20,29)$. Although none of these patients were given more than 125 grams of protein daily, the capacity to store the excess protein with maximum efficiency was definitely surpassed.

In the present series of nephritic patients the amounts of protein taken seldom exceeded 125 grams and were usually much smaller. In most cases they were limited less by the physicians than by the appetites and digestions of the patients. When the patients were not afflicted by any complicating wasting disease and were able to consume over long periods enough protein to supply the endogenous metabolic needs plus enough to replace that lost in the urine and a further additional amount to restore previously depleted tissues, the serum proteins rose and edema disappeared. Although proteinuria continues unchanged, such patients have been enabled to pursue normal active lives for periods of years. This is true not only of patients with apparently idiopathic nephrosis, but those with the nephrotic form of glomerular nephritis, such as 61090 and 95123 . Case 56577 shows that even a patient with amyloid nephrosis may become free from edema and 
undergo a temporary remission if the underlying chronic infection becomes sufficiently arrested to permit restoration of the normal nutritive state.

Whether this treatment has any definite effect in checking the progress of the disease and aiding repair of the renal lesion is doubtful, although it is not unreasonable to suppose that, by improving general health and nutrition, it may facilitate reparative processes. Two of the patients in this series, 80351 and 62246, appear to have recovered completely, the latter after an illness of almost three years' duration.

Berglund and Scriver (34), Cowie, Jarvis and Cooperstock (27) and others claim that proteinuria is increased by high protein diets. Within the dietary limits employed in the present study no relation could be found between dietary and urinary protein.

Epstein $(2,33)$ advocates limitation of dietary fat in the treatment of nephrosis, because lipemia is so consistently encountered in this condition. Unless it can be proved that the lipemia is due to faulty fat metabolism, which seems unlikely (35), fat restriction does not seem to be clearly indicated. In order to secure maximum utilization of protein and to overcome malnutrition it is necessary to furnish adequate calories. This is almost impossible unless fat is given freely. There is no evidence in these studies that diets containing generous proportions of fat had any deleterious effects.

If the reductions of basal metabolism so frequently encountered are referable to edema and malnutrition, the administration of thyroid, which has been advocated by Epstein $(2,30)$, does not seem entirely logical. The low basal metabolism must be considered as a conservative process, and therefore one to be furthered and not combatted. Administration of thyroid to two of the cases of this series with low basal metabolism, 34753 and 62246, did not promote diuresis nor exert any other favorable effect, although it was pushed to the point where disagreeable symptoms appeared. Nor did these patients, as Epstein reports, exhibit any peculiar tolerance for the drug. It may be that the greater tolerance and beneficial effects reported by others are products of age and not disease. Most of these subjects have been children. It has been shown by Topper and Cohen (36) that in childhood thyroid does not produce symptoms of hyperthyroidism and may promote growth. 
Although salt restriction and diuretic drugs, especially acidifying salts and urea, are useful measures in initiating diuresis, they should be considered only as temporary palliative measures and certainly should not be forced to the point where they interfere with appetite or digestion.

\section{CONCLUSIONS}

Reduction of serum proteins at the expense of the albumin fraction is not characteristic of idiopathic nephrosis, but is equally common in other types of nephritis with non-cardiac edema.

When the proteins, by reason of albumin deficiency fall below 5 , but remain above 4 per cent, edema is likely to appear, but can usually be eliminated by proper therapeutic measures. When they fall below 4 per cent treatment is usually ineffectual.

Besides albuminuria, which permits direct loss of serum albumin into the urine, the chief cause of the serum protein deficiency appears to be depletion of the protein stores of the body.

\section{PROTOCOLS}

\section{Chronic glomerular nephritis}

35628: A Polish male, aged 43, developed generalized edema after a sore throat in August, 1924. He was admitted to the Hospital January 10, 1925, with slight anemia, general anasarca, blood pressure 122/78, phenolsulfonphthalein excretion of 32 per cent, blood nonprotein nitrogen of $61 \mathrm{mgm}$. per $100 \mathrm{cc}$., an inflamed throat and slight fever, urine containing blood and casts and from 8 to 19 grams of protein daily. On discharge he was free from edema, the blood nonprotein nitrogen was $30 \mathrm{mgm}$. per $100 \mathrm{cc}$, and the urine contained no red blood cells, although the proteinuria had not diminished. The patient has not been seen again.

61711: A boy, aged 5, developed generalized edema after a sore throat and otitis media, in November, 1926. He was admitted to the hospital September 11, 1927, with general anasarca, secondary anemia, a blood pressure of $100 / 80$, blood nonprotein nitrogen $22 \mathrm{mgm}$. per $100 \mathrm{cc}$., and urine containing large amounts of protein without macroscopic or microscopic blood. $\mathrm{He}$ failed to respond to any therapeutic measures, had repeated upper respiratory infections (apparently due to the hemolytic streptococcus) and finally died January 2,1928, of hemolytic streptococcus septicemia with peritonitis. Autopsy revealed in the kidneys glomerular nephritis, extensive tubular degeneration and focal lesions, presumably connected with the septicemia.

61090: An unmarried woman of 29, in March, 1927, developed generalized edema without any antecedent infection. She was admitted to the hospital 
July 7 with general anasarca, blood pressure of 160/108, phenolsulfonphthalein excretion of 15 per cent, a blood nonprotein nitrogen of $77 \mathrm{mgm}$. per $100 \mathrm{cc}$. and a urine containing 10 to 15 grams of protein daily, many casts, a few leucocytes, but no red blood cells. After a period of resistance to treatment she developed a profuse diuresis and improved rapidly. At the time of discharge, October 31, she was free from edema, with a blood pressure of $124 / 96$, blood nonprotein nitrogen of 29 , without change in the urinary picture. The blood count gradually returned to normal and she improved steadily after her discharge. She was soon able to resume her occupation as cook and houseworker and felt entirely well until December 18, 1930, when she developed a severe upper respiratory infection. Edema recurred and she was finally admitted to the hospital January 21 with moderate general anasarca, but with normal blood pressure and a blood nonprotein nitrogen of 30. She improved rapidly under treatment, was discharged February 2 free from edema and was able to resume work a little later. The urine from the first observation to the present time, June 10, 1931, including the symptomless periods, has remained unchanged, always containing large amounts of protein, many casts and a few leucocytes, with only occasionally rare red blood cells.

34854: A Polish male, aged 29, was admitted to the hospital October 14, 1924. Two years earlier after an acute polyarthritis he developed general anasarca, hematuria and lumbar pain. These symptoms persisted with exacerbations and remissions, the former usually accompanying sore throats. On admission he presented general anasarca, secondary anemia, a blood pressure of $155 / 95$, a phenolsulfonphthalein excretion of 45 per cent, blood nonprotein nitrogen of $43 \mathrm{mgm}$. per $100 \mathrm{cc}$., and urine containing 10 to 15 grams of protein daily, many casts, some leucocytes, and, at intervals, numerous red blood cells. In addition the heart was enlarged, a loud systolic murmur was audible over the whole precordium, the spleen was considerably enlarged and hard, and he exhibited intermittent tenderness in both costovertebral angles, occasional arthritic manifestations and irregular fever. Under treatment, after a considerable latent period, he developed diuresis. and improved greatly. When discharged, on December 22, he was free from. edema, the anemia had improved, the blood pressure was $131 / 85$, the blood nonprotein nitrogen $28 \mathrm{mgm}$. per $100 \mathrm{cc}$. The urine was unchanged. Just: after his discharge he caught cold, developed pneumonia, and was admitted to a Hartford Hospital with recurrence of all the nephritic symptoms. June 23, 1925, he was readmitted to the New Haven Hospital, where he remained until his death, October 8, 1925. Except for greater emaciation and anemia. his condition was essentially the same as it had been on the previous admission. Under strict treatment he could be kept free from edema; blood pressure and blood nonprotein nitrogen remained normal. Irregular fever and intermittent temperature persisted, hematuria was more frequent and profuse and he suffered from attacks of sharp pain in the regions of the spleen 
and kidneys. September 19 he had a transient attack of unconsciousness, followed by vomiting and severe headache. The spinal fluid was found to be bloody. October 8 , he had a sudden convulsion and died a few hours later. Autopsy revealed a cerebral hemorrhage, a small, fresh vegetation on the mitral valve, old and fresh infarctions of spleen and kidneys. In the latter there were also extensive tubular degenerations, signs of chronic and acute glomerular nephritis, and lesions of a more acute, probably bacterial, diffuse focal nephritis.

56883: A male, in 1922, at the age of 16 , developed nephritis with hematuria after an acute respiratory infection. The acute symptoms rapidly subsided, but he was left with persistent albuminuria and occasional periods of hematuria. In March, 1927, he spent 17 days in the hospital under observation. He was entirely free from symptoms, without edema or anemia. His blood pressure was 120/86, phenolsulfonphthalein excretion 56 per cent, and his blood nonprotein nitrogen varied from 40 to $21 \mathrm{mgm}$. per $100 \mathrm{cc}$. The urine contained 3 to 4 grams of protein daily, casts, and moderate numbers of leucocytes, but no red blood cells.

95123: A female, in 1922, at the age of 19, developed general anasarca after a sore throat. The edema persisted to a variable extent after subsidence of the acute attack. When she was first seen as an outpatient on June 22, 1928, she had moderate edema of the legs, no anemia, a blood pressure of $136 / 86$, and a blood nonprotein nitrogen of $20 \mathrm{mgm}$. per $100 \mathrm{cc}$. The urine contained 7 to 10 grams of protein daily, some casts and occasional leucocytes and red blood cells. After preliminary treatment with urea she became free from edema and remained so until the summer of 1930, when she reduced her diet for the sake of her figure. Shortly after this she developed anasarca and, November 12,1930, was admitted to the hospital. Her edema disappeared with rest in bed and salt poor, high protein diet. After discharge she remained free from edema, at first with the aid of urea, later without. The blood pressure and blood nonprotein nitrogen remained normal throughout; the urine unchanged.

83166: A male, aged 31, in February, 1930, began to suffer from pain in the back and the lower abdomen; relieved by urination, accompanied by edema of the ankles. The edema gradually increased and dyspnea on exertion and palpitation developed. In March the blood pressure was found elevated, the lower trunk had become edematous and ascites had appeared. When admitted to the hospital, April 15, he presented signs of chronic tonsillar infection, râles and dulness at the bases of both lungs, ascites and edema of the lower extremities and the lower part of the trunk, a blood pressure of 140/90, 70 per cent phenolsulfonphthalein excretion, and a blood nonprotein nitrogen of $44 \mathrm{mgm}$. per $100 \mathrm{cc}$. The urine contained 10 to 12 grams of protein daily, casts, a few leucocytes and rare red blood cells. He improved gradually under treatment until May 26, when he developed a sore throat and bronchopneumonia. With this the blood pressure rose, the blood 
nonprotein nitrogen increased to $60 \mathrm{mgm}$. and vomiting began. June 2 , he went into convulsions. He was discharged against advice August 2. The blood pressure at this time was 150/100, the blood nonprotein nitrogen 76 mgm. per $100 \mathrm{cc}$. The character of the urine had not changed. The patient died at home shortly after he left the hospital.

$F$. M.: A female, aged 14, in 1927 , after a sore throat, was discovered to have profuse albuminuria. After this she noticed that her eyelids became puffy at irregular intervals. When seen as an outpatient, December 16, 1930, she seemed well. There was no edema, no anemia, a blood pressure of 110/80, 50 per cent phenolsulfonphthalein excretion and a blood nonprotein nitrogen of $34 \mathrm{mgm}$. per $100 \mathrm{cc}$. The urine contained about 3 grams of protein per day, rare casts, leucocytes and red blood cells. Her condition has remained unchanged until the present, June 22, 1931.

\section{Amyloid nephrosis}

34753: A male, aged 19, was admitted to the hospital October 2, 1924, because of a severe diarrhea of 5 weeks' duration. This diarrhea persisted until death. June 10,1926, his feet became swollen and albumin was detected. He was admitted to the hospital again on June 14 and followed in the hospital or as an outpatient until death with acute peritonitis symptoms, February 12, 1928. Throughout this period of study the diarrhea and edema persisted, the blood pressure and blood nonprotein nitrogen remained normal, the urine contained from 7 to 20 grams of protein daily, casts and leucocytes, but no red blood cells. Autopsy revealed proliferative tuberculous enteritis and general amyloid disease with amyloid nephrosis.

56577: A female, in 1920, at the age of 12, developed an abscess of the os innominatum. After this she had repeated abscesses of the pelvic bones and one of the ribs. In January, 1927, during the surgical treatment of one of these abscesses in this hospital, generalized anasarca appeared. The urine was found to contain large amounts of albumin, with casts and leucocytes, but no red blood cells. The blood pressure and blood nonprotein nitrogen were normal. After a protracted illness the edema cleared and the abscess healed. The proteinuria diminished considerably. From August, 1928, she remained free from abscesses and symptoms of all kinds until December, 1930 , when she had a recurrence of the pelvic osteomyelitis, which opened into the bladder. The edema recurred. Operation was unsuccessful and she died on April 11, 1931. The blood pressure was always normal, the blood nonprotein nitrogen rose only as a terminal event. Autopsy revealed osteomyelitis of the symphysis, pelvic peritonitis and amyloid nephrosis.

7\%481: A male, developed pulmonary tuberculosis in 1927 at the age of 27. In September, 1928, after he had lost $26 \mathrm{lbs}$. of weight, diarrhea and edema of the legs appeared. When he was admitted to the hospital January 13,1929 , besides evidences of advanced pulmonary tuberculosis, he had gen- 
eral anasarca, anemia, enlargement of the liver and spleen, a blood pressure of $110 / 80$, and a blood nonprotein nitrogen of $43 \mathrm{mgm}$. per $100 \mathrm{cc}$. The urine contained large amounts of protein, many casts and a few leucocytes. He died suddenly on January 24th. Autopsy revealed extensive ulcerative pulmonary tuberculosis, purulent pleurisy on the left, purulent pericarditis, tuberculous enteritis and amyloid disease with nephrosis.

72804: A male, aged 21, developed edema of the ankles in August, 1928. Three months later he noticed a productive cough. On admission to the hospital, February 13, 1929, he presented signs of extensive pulmonary tuberculosis, slight left sided pleural effusions, ascites, enlargement of the liver, marked edema of the lower extremities and back, secondary anemia, a blood pressure of $128 / 80$, and blood nonprotein nitrogen of $25 \mathrm{mgm}$. per $100 \mathrm{cc}$. The urine contained 10 to 17 grams of protein daily, with casts and leucocytes, but no red blood cells. The patient was discharged to a sanatorium March 13.

58114: A male, in 1920, at the age of 32, developed pulmonary tuberculosis. Treatment was neglected until 1926, when he went to a sanatorium for sixteen months. In July, 1930, he developed abdominal distress, vomiting, diarrhea, and edema. On admission to the hospital, August 29, 1930, he had extensive, bilateral, pulmonary tuberculosis, ascites, edema of the lower extremities and back, a blood pressure of 120/86, 60 per cent phenolsulfonphthalein excretion and a blood nonprotein nitrogen of $41 \mathrm{mgm}$. per $100 \mathrm{cc}$. The urine contained large amounts of albumin, casts and leucocytes, but no. red blood cells. He became progressively weaker and died on September 20th.

50265: A male, in 1919, at the age of 29, developed pulmonary tuberculosis. In 1924, backache and edema of the ankles appeared and persisted with remissions until his admission to the hospital on April 26, 1926. At that time he had signs of active pulmonary tuberculosis at one apex, edema. of the lower extremities, a blood pressure of 143/95, 60 per cent phenolsulfonphthalein excretion and a blood nonprotein nitrogen of $27 \mathrm{mgm}$. per $100 \mathrm{cc}$. The urine contained 11 grams of protein a day and many casts, but no leucocytes nor red blood cells. The edema rapidly disappeared under treatment and the patient was discharged May 11, free from symptoms. The proteinuria, however, remained unchanged.

15544: A female, developed diabetes in 1918, at the age of 47 . She was. admitted to the hospital January 30,1923 , because of an ulcer on the right ankle. She proved to have a mild diabetes, generalized arteriosclerosis, a peculiarly disseminated sclerosis of the spinal cord without gastric achlorhydria or anemia, signs of apical pulmonary tuberculosis and enlargement of the liver. From this time on she was admitted at intervals, usually for injuries or infections of the extremities. In June, 1923, a profuse albuminuria was discovered. In November, 1928, she developed increasing edema, weakness and dyspnea. When admitted to the hospital, September 29, 1929, she 
had, besides the previous findings, anemia, edema of the lower extremities and back, ascites, a blood pressure of 220/110, 30 per cent phenolsulfonphthalein excretion and a blood nonprotein nitrogen of $46 \mathrm{mgm}$. per $100 \mathrm{cc}$. The urine contained 9 to 13 grams of protein, many leucocytes and some casts, but no red blood cells. Her condition became steadily worse and she died November 4.

\section{Cases of unknown origin}

31190: Male, aged 52, developed edema of the legs early in May, 1924. Ten months earlier he had contracted syphilis, for which he was treated with arsenical injections for 6 months. When he was admitted to the hospital on May 24 he had moderate edema of the lower extremities and back, a blood pressure of 140/80, 45 per cent phenolsulfonphthalein excretion, a blood nonprotein nitrogen of 32 , and a positive blood Wassermann. The urine contained a large amount of protein, many casts and a few leucocytes and red blood cells. Under treatment in the hospital the edema diminished rapidly. However, it recurred when he left the hospital. When he was seen a year later he still had some orthostatic edema and the urine had not cleared; but his blood pressure and blood nonprotein nitrogen were normal.

73282: A male, aged 17, in the middle of February, 1929, was seized with abdominal pain, vomiting, chills and temperature. Three days later albuminuria was discovered. The vomiting continued and edema gradually developed. When he entered the hospital March 27, he had general anasarca, anemia, a blood pressure of $118 / 72$, a 15 per cent phenolsulfonphthalein excretion, and a blood nonprotein nitrogen of $72 \mathrm{mgm}$. per $100 \mathrm{cc}$. The urine contained 10 to 16 grams of protein per day, many casts and a few leucocytes, but no red blood cells. Vomiting persisted after admission, accompanied by headache. May 6 he developed diarrhea and increasing abdominal pain and tenderness with fever. On May 7 precordial pain appeared and May 10, harsh pleural friction on the right side. He died on May 10. Between May 6 and the day of death pneumococci, Group IV, were secured from 3 different blood cultures. An indefinite history of sore throat and rash just preceding the nephritis was obtained.

83434: A male, aged 68, developed pain in the joints of the upper extremities and in the back in May, 1929. November 19 he noticed edema of the lower extremities. In December he was found to have complete heart block and albuminuria was discovered. In March, 1930, the pains extended to the lower extremities and the edema increased to involve the trunk. When seen at his home, May 3, he had marked edema of all four extremities and the lower trunk, double hydrothorax, ascites, heart block, a blood pressure of $120 / 60$, severe anemia, and a blood nonprotein nitrogen of $80 \mathrm{mgm}$. per 100 cc. The urine contained 13 grams of protein per day, with few casts or cells. May 18 he was admitted to the hospital, where he died on May 25. 
29122: A male, aged 30, was admitted to the hospital February 2, 1924, because of edema which had appeared shortly before that without any antecedent infection. On admission he had general anasarca, a blood pressure of 105/65, 55 per cent phenolsulfonphthalein excretion and a blood nonprotein nitrogen of $33 \mathrm{mgm}$. per $100 \mathrm{cc}$. His urine contained 10 to 15 grams of protein daily, with many casts, but no red blood cells. The edema disappeared rapidly under treatment in the hospital.

80851: A male, aged 19, without known antecedent infection, in March, 1928, developed edema, ascites, and albuminuria which persisted for four months. In March, 1929, he had a second similar attack which cleared up more rapidly. July 15, 1929, he was admitted to the hospital because of recurrence of albuminuria. There was no edema, the blood pressure was 124/64, phenolsulfonphthalein excretion 50 per cent, blood nonprotein nitrogen $25 \mathrm{mgm}$. per $100 \mathrm{cc}$., and blood count normal. The urine remained clear while he was in the hospital. Early in September dizziness, anorexia, back pain and headache set in, associated with albuminuria. He was again admitted to the hospital, where the symptoms and urinary changes disappeared. His tonsils were removed because of a history of frequent sore throats. In November pain in the flanks recurred, accompanied by edema and profuse proteinuria. When he entered the hospital, November 19, he had general anasarca without anemia, hypertension or azotemia. His urine contained 6 to 8 grams of protein daily, with casts and leucocytes, but no red blood cells. Under treatment the edema gradually disappeared and the proteinuria diminished. By March, 1930, all signs of renal disease had disappeared. There has been no recurrence up to the present time (July, 1931). Industrial mercury poisoning may have been the etiological factor in this case.

62246: A female, aged 30, in June, 1927, without antecedent infection, developed edema of the feet and some breathlessness. These symptoms lasted only about 2 weeks, but recurred again in October, when albuminuria was discovered. When she was admitted to the hospital, November 1, 1927, she had moderate edema of the legs, thighs and lower back, slight anemia, a blood pressure of 105/75, 30 per cent phenolsulfonphthalein excretion and a blood nonprotein nitrogen of $32 \mathrm{mgm}$. per $100 \mathrm{cc}$. The urine contained about 10 grams of protein daily, with occasional casts and leucocytes, but no red blood cells. The edema, although moderate, was extremely resistent to treatment. The patient suffered continuously from anorexia and digestive disturbances. However, she improved gradually and, by October, 1928, the edema had disappeared, although the proteinuria persisted unabated. She was seen at infrequent intervals without evidence of change in the condition until in May, 1930, a distinct reduction of the proteinuria was noted. Shortly after this date the urine cleared completely. Examination in October, 1930, revealed no evidences of renal disease. 


\section{BIBLIOGRAPHY}

1. Bruckman, F. S., D'Esopo, L. M., and Peters, J. P., J. Clin. Invest., 1930, viii, 577. The Plasma Proteins in Relation to Blood Hydration. IV. Malnutrition and the Serum Proteins.

2. Epstein, A. A., Am. J. Med. Sci., 1922, clxiii, 167. Further Observations on the Nature and Treatment of Chronic Nephrosis.

3. Peters, J. P., Wakeman, A. M., Eisenman, A. J., and Lee, C., J. Clin. Invest., 1929, vi, 577. Total Acid-Base Equilibrium of Plasma in Health and Disease. XII. A Study of Renal Edema.

4. Rowe, A. H., Arch. Int. Med., 1916, xviii, 455. The Albumin and Globulin Content of Human Blood Serum in Health, Syphilis, Pneumonia and Certain Other Infections, with the Bearing of Globulin on the Wassermann Reaction.

5. Moore, N. S., and Van Slyke, D. D., J. Clin. Invest., 1930, viii, 337. The Relationship between Plasma Specific Gravity, Plasma Protein Content and Edema in Nephritis.

6. Cope, C. L., Quart. J. Med., 1928, xxii, 91. The Osmotic Pressure of the Blood Proteins in Nephritis.

7. Wiener, H. J., and Wiener, R. E., Arch. Int. Med., 1930, xlvi, 236. Plasma Proteins.

8. Fahr, G., Kerkhoff, A., and Conklin, C., Proc. Soc. Exp. Biol. and Med., 1931, xxviii, 718. Normal Osmotic Pressure of the Plasma Proteins of Man.

9. Sörensen, S. P. L., Harvey Lectures, 1924-25, 25. The Solubility of Proteins.

10. Cohn, E. J., Hendry, J. L., and Prentiss, A. M., J. Biol. Chem., 1925, lxiii, 721. Studies in the Physical Chemistry of the Proteins. V. The Molecular Weight of the Proteins. Part I. The Minimal Molecular Weights of Certain Proteins.

11. Govaerts, M. P., Bull. Acad. roy. de méd. de Bélgique, 1927, vii, 356. Influence de la teneur du sérum en albumines et en globulines sur la pression osmotique des protéines et sur la formation des oedèmes.

12. Starling, E. H., J. Physiol., 1895-96, xix, 312. On the Absorption of Fluids from the Connective Tissue Spaces.

13. Salvesen, H. A., Acta Med. Scandinav., 1926-27, 1xv, 152. Hyperproteinemia in a Case of Nephrosis.

14. Linder, G. C., Lundsgaard, C., Van Slyke, D. D., and Stillman, E., . J. Exp. Med., 1924, xxxix, 921. Changes in the Volume of Plasma and Absolute Amount of Plasma Proteins in Nephritis.

15. Brown, G. E., and Rowntree, L. G., Arch. Int. Med., 1925, xxxv, 129. The Volume and Composition of the Blood and the Changes Incident to Diuresis in Cases of Edema. Arch. Int. Med., 1928, xli, 44. Blood Volume in Edema of Glomerular Nephritis and Nephrosis. 
16. Darrow, D. C., Proc. Soc. Exp. Biol. and Med., 1926, xxiii, 740. The Blood Volume in Cases of Nephritis with Edema and Low Serum Protein Concentration.

17. Kerr, W. J., Hurwitz, S. H., and Whipple, G. H., Am. J. Physiol., 1918, xlvii, 356. Regeneration of Blood Serum Proteins. I. Influence of Fasting upon Curve of Protein Regeneration Following Plasma Depletion. Am. J. Physiol., 1918, xlvii, 370. II. Influence of Diet upon Curve of Protein Regeneration Following Plasma Depletion.

18. Leiter, L., Arch. Int. Med., 1931, xlviii, 1. Experimental Nephrotic Edema.

19. Frisch, R. A., Mendel, L. B., and Peters, J. P., J. Biol. Chem., 1929, lxxxiv, 167. The Production of Edema and Serum Protein Deficiency in White Rats by Low Protein Diets.

20. Bruckman, F. S., and Peters, J. P., J. Clin. Invest., 1930, viii, 591. The Plasma Proteins in Relation to Blood Hydration. V. Serum Proteins.and Malnutritional or Cachectic Edema.

21. Ling, S. M., Chinese J. Physiol., 1931, v, 1. Changes of Serum Proteins in Undernutrition.

22. Weech, A. A., and Ling, S. M., J. Clin. Invest., 1931, x, 869. Nutritional Edema. Observations on the Relation of the Serum Proteins to the Occurrence of Edema and to the Effect of Certain Inorganic Salts.

23. Peters, J. P., J. Am. Dietetic Assoc. 1926, ii, 137. The Principles of Diet Control in Nephritis with Especial Reference to Protein and Salt Restriction.

24. Peters, J. P., and Bulger, H. A., with Lee, C., and Murphy, C. F., Arch. Int. Med., 1926, xxxvii, 153. The Relation of Albuminuria to Protein Requirements in Nephritis.

25. Mason, E. H., International Clinics, 1926, 1, series 36, 163. The Life History of a Case of Nephrosis.

26. Rabinowitch, I. M., and Childs, M. C. C., Arch. Int. Med., 1923, xxxii, 758. A Contribution to the Biochemistry and Treatment of Chronic Nephrosis.

27. Cowie, D. M., Jarvis, K. M., and Cooperstock. M., Am. J. Dis. Child., 1930, xl, 465. Metabolism Studies in Nephrosis with Special Reference to the Relationship of Protein Intake to Nitrogen Retention, Edema and Albuminuria.

28. Mason, E. H., Canad. Med. Assoc. J., 1924, xiv, 1052. The Treatment of Obesity.

29. von Hoesslin, H., Arch. f. Hyg., 1919, lxxxviii, 147. Klinische Eigentümlichkeiten und Ernährung bei schwerer Inanition.

30. Epstein, A. A., J. Am. Med. Assoc., 1926, lxxxvii, 913. Thyroid Therapy and Thyroid Tolerance in Chronic Nephrosis. 
31. Epstein, A. A., and Lande, H., Arch. Int. Med., 1922, xxx, $563 . \quad$ Studies on Blood Lipoids. I. The Relation of Cholesterol and Protein Deficiency to Basal Metabolism.

32. Lusk, G., Physiol. Rev., 1921, i, 523. The Physiological Effect of Undernutrition.

33. Epstein, A. A., Am. J. Med. Sci., 1917, cliv, 638. Concerning the Causation of Edema in Chronic Parenchymatous Nephritis: Method for its Alleviation.

34. Berglund, H., and Scriver, W., Am. J. Physiol. (Soc. Proc.), 1926, lxxvi, 190. Studies in Albuminuria.

35. Hiller, A., Linder, G. C., Lundsgaard, C., and Van Slyke, D. D., J. Exp. Med., 1924, xxxix, 931. Fat Metabolism in Nephritis.

36. Topper, A., and Cohen, P., Am. J. Dis. Child., 1928, xxxv, 205. The Effect of Thyroid Therapy on Children.

37. Moore, D. D., Lavietes, P. H., Wakeman, A. M., and Peters, J. P., J. Biol. Chem., 1931, xci, 373. The Effect of Ingested Urea on Nitrogen Metabolism. 